DOI: $10.17580 /$ cisisr.2020.02.04

\title{
IMPROVEMENT OF MECHANICAL PROPERTIES OF IRON CASTINGS VIA ADJUSTING OF SOLIDIFICATION RATE
}

\author{
N. I. Gabelchenko' , A. A. Belov¹, N. A. Kidalov' ${ }^{1}$, A. I. Gabelchenko² \\ ${ }^{1}$ Volgograd State Technical University (Volgograd, Russia); \\ 2 Lomonosov Moscow State University (Moscow, Russia)
}

E-mail: aa-belov@br.ru; mitlp@vstu.ru

\author{
AUTHOR'S INFO \\ N. I. Gabelchenko, Cand. Eng., \\ Associate Prof., Dept. "Machines \\ and technology of casting \\ production"; \\ A. A. Belov, Senior Lecturer, \\ Dept. "Machines and technology \\ of casting production"; \\ N. A. Kidalov, Dr. Eng., Prof., \\ Head of Dept. "Machines \\ and technology of casting \\ production"; \\ A. I. Gabelchenko, Junior \\ Scientific Researcher \\ Key words: \\ casting, iron, tensile strength, cooling \\ rate, exothermic carbon-containing \\ additives, eutectic transformation, \\ eutectoid transformation, crystalliza- \\ tion, solidification.
}

\begin{abstract}
A B S T RACT
The work is devoted to improvement of mechanical properties of iron castings via adjusting of the cooling rate without introduction of alloying additives. The new technological solution is suggested; it can be easily adapted to a casting technology. This solution is based on variation of the cooling rate of iron castings within structurally sensitive solidification intervals. For this purpose, the casting mould was initially cooled after pouring, then heated and cooled again. Cooling of the mould during the period of primary austenite crystal forming led to increase of dendrite crystallization rate and was executed using compressed air. Retarding of the cooling rate during the period of eutectic transformation was provided by the mould heating via burning of exothermic carbon-containing additives introduced in a facing layer of sand-clay moulding mix. Burning reaction is accompanied by heat extraction, what steeply retarded the cooling rate within the interval of eutectic transformation. Consequent acceleration of castings cooling within the interval of eutectoid transformation was achieved via repeated air blowing through a worked reaction layer. Adjusted cooling of iron castings allowed to provide the most favourable solidification conditions, taking into account strictly individual requirements for each structurally sensitive temperature intervals. It led to increase of a volumetric part of primary austenite dendrite crystals, to decrease of eutectic transformation overcooling degree, to forming of graphite eutectics and enlargement of dispersity of pearlite component in iron. Consequently, lowering of widespread iron castings rejects takes place, among them chilling, with simultaneous improvement of metal mechanical properties.

As a result, the primary and real structures were varied, what had a positive effect on mechanical properties of casting metal. It is shown that use of solidification rate adjustment led to essential increase of metal tensile strength for the experimental casting.
\end{abstract}

\section{Introduction}

Grey iron is at present time the main structural material in machine-building owing to combination of high casting properties, sufficient strength and wear resistance. Relatively low liquidus temperature and narrow temperature interval of crystallization provide good casting properties of machine-building grey iron, such as high castability and small shrinkage.

Usual crystallization of low-carbon and low-silicon iron does not provide obtaining of stable high properties in castings and is accompanied by appearance of deep chilling. High level of mechanical properties in such iron is obtained via melt modifying, e.g. by ferrosilicon or calcium silicon [1-3]. The components operated at increased temperature usually require use of alloyed grey iron containing additionally chromium, nickel, molybdenum and aluminium $[1,4,6]$.

At the same time grey iron is considered as a structural material that is very sensitive to thermal kinetic conditions of crystallization and cooling [5,7-10]. Variation of properties takes place in this grey iron depending on the cooling rate, and in general they can be compared with application of alloying additives.

Increase of the cooling rate in the temperature interval of iron solidification is accompanied by enlargement of dispersity of eutectic cells, decrease of total amount of eutectic component and increase of the amount of primary austenite dendrite crystals. Eutectics of grey iron, i.e. austenite-graphite eutectics, can become meta-stable and austenite-cementite one (ledeburite) at high cooling rate values [7-12]. In this case grey iron becomes white iron and correspondingly its properties vary principally. Cooling retarding or acceleration of iron casting in the recrystallization temperature interval is inevitably reflected on pearlite and ferrite correlation in the structure of metallic base. If the cooling rate is increased (what is typical for thin-wall castings), pearlite amount in the structure increased, as well as its dispersity. If the cooling rate is retarded, ferrite amount increased, while pearlite becomes at first medium-laminar and later coarse-laminar, losing substantially its hardness and strength [5-9].

Thereby, structure forming of grey iron occurs in several structurally sensitive temperature intervals, and each of them requires individual cooling rate to achieve the best complex of mechanical and technological properties for castings.

Unidirectional variation of the cooling rate of metal casting is widely practically used to obtain the required results [11-16]. If the cooling rate is increased, forming of cementite eutectics is very possible, what can lead to chilling. If the cooling rate is retarded in the eutectic interval, it allows to get reliably grey iron castings with formed graphite eutectics. 
This research was aimed on variation of the metal casting cooling rate within the structurally sensitive solidification intervals in order to improve mechanical properties of grey iron castings.

\section{Materials and methods of investigation}

Experimental equipment allowing to produce simultaneously experimental and control castings was developed and manufactured for investigation of the effect of castings cooling rate in moulds. Dimensions of castings were $120 \times 60 \times 10 \mathrm{~mm}$. The control casting was isolated from the experimental one, while exothermal reaction of carbon-containing additive was initiated around the experimental casting; it was accompanied by steep retarding of heat removal in the mould. Increase of cooling rate of the experimental casting was realized via compressed air feed under 3 atmospheres pressure in the beginning of dendrite crystallization, and it was finished after forming of primary austenite crystals. Then burning process of exothermal carbonbearing additive was initiated by oxygen from blown air. The temperatures of structurally sensitive crystallization intervals of poured cast iron were determined preliminary by the results of differential thermal analysis, using software complex "Kristallograf" together with the technique described in [17].

Activation of exothermal carbon-containing additive and heat extraction at the stage of eutectics forming occurred to the moment of eutectic transformation. Management of burning reaction start was undertaken via choosing consumption of fed compressed air and amount of introduced carbon-containing additive. It should be noted that such technique allowed to start and stop exothermal burning reaction of carbon-containing additive practically immediately, via feed or stopping feed of compressed air in the casting mould at the required moment determined by the temperature of structurally sensitive intervals [14]. The exothermal carbon-containing additive - M-100 fuel oil (according to GOST 10585-2013), combining large amount of extracted heat and maximal mass loss during heating together with low gas forming was chosen for retarding of the cooling rate in the interval of eutectic transformation, based on preliminary thermogravimetric researches of the ten carbon-containing materials [18], The additive was introduced in the amount of $2.5 \%$ (mass.) above $100 \%$ in the experimental casting composition of facing layer of moulding mix containing 94\% (mass.) of sand from Orlovskiy sand quarry (grade 2K2O202 according to GOST 2138-91) and 6\% (mass.) of bentonite clay (BS1T2 according to GOST28177-89). Humidity of moulding mix made $3.5 \%$. Thickness of facing layer was $10 \mathrm{~mm}$. As soon as the experimental casting reached overcritical temperature of eutectoid transformation, the mould was blown again by air under the same pressure. Increase of the cooling rate in the interval of eutectoid transformation was achieved due to secondary

Table 1. Chemical composition of researched cast iron, mass.\%
\begin{tabular}{|c|c|c|c|c|c|c|c|c|c|c|}
\hline $\mathrm{C}$ & $\mathrm{Mn}$ & $\mathrm{Si}$ & $\mathrm{P}$ & $\mathrm{S}$ & $\mathrm{Cr}$ & $\mathrm{Ni}$ & $\mathrm{Cu}$ & $\mathrm{Mo}$ & $\mathrm{V}$ & $\mathrm{Fe}$ \\
\hline 3.30 & 0.55 & 1.72 & 0.073 & 0.111 & 0.173 & 0.118 & 0.162 & 0.010 & 0.013 & Res. \\
\hline
\end{tabular}

air filtration through already processed reaction layers. Comparison of the obtained results was realized by simultaneous recording of castings cooling curves with adjusting and non-adjusting cooling in the experimental casting mould. Temperature of castings was measured by "A" type thermocouples (BP5/BP20 tungsten-rhenium thermocouple). DFS-500 spectrometer was used for determination of chemical composition of castings metal.

Experimental melting was conducted in the induction melting furnace IPP-15 (GW-MF-15) in the laboratory of Volgograd State Technical University (VolgSTU).

Hypoeutectic cast iron was taken as a research object. Its chemical composition is presented in the Table $\mathbf{1 .}$

Carbon equivalent $\left(C_{E}\right.$ ) is equal to $3.874 \%$, eutecticity degree $(S c)$ is 0.885 , calculated via the technique [19].

After pouring the experimental mould by liquid cast iron and consequent cooling, the castings were knocked out and the following samples were manufactured: for mechanical testing on the pull test machine IP 5082-100 (according to the GOST 1497-84), for hardness determination via Brinell method on the hardness tester TB 5004 (according to the GOST 9012-59) and for metallographic analysis on the microscope OLYMPUS BX51M. The chemical reagent No. 54 was used for reveal of primary structure [20]. Dispersity of dendrite structure was evaluated by the distance between the $2^{\text {nd }}$ order branches. Size of eutectic cells was measured by the linear analysis method, including overlapping of the family of measuring straight lines on the structure image. $4 \%$ solution of nitric acid $\mathrm{HNO}_{3}$ in ethylic alcohol $\mathrm{C}_{2} \mathrm{H}_{5} \mathrm{OH}$ was used for pickling of samples for real structure (according to the GOST 3443-87).

\section{Results of investigation and their discussion}

Cooling curves of the control and experimental castings are presented on the Fig. 1.

The picture displays that cooling rate of the experimental casting can be increased practically by

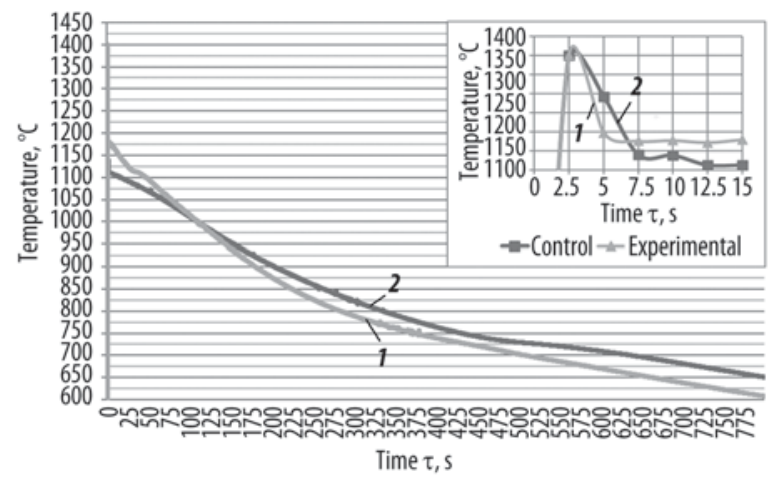

Fig. 1. Cooling curves of the experimental (1) (with cooling adjusting) and control (2) castings 

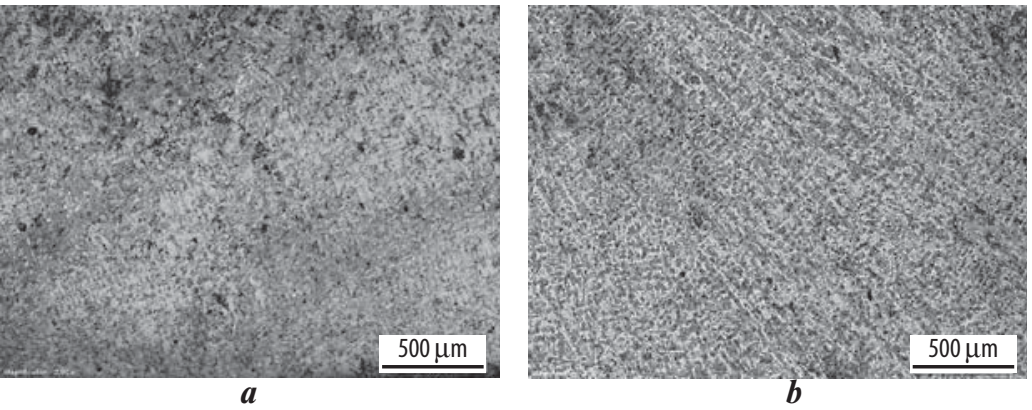

Fig. 2. Dendrite metal structure for control ( $a$ ) and experimental (b) castings
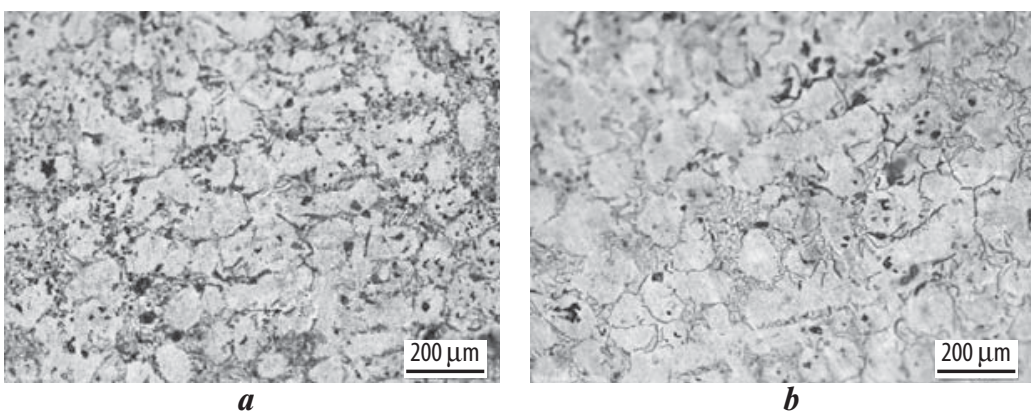

Fig. 3. Cast iron eutectic cells for control ( $a$ ) and experimental (b) castings
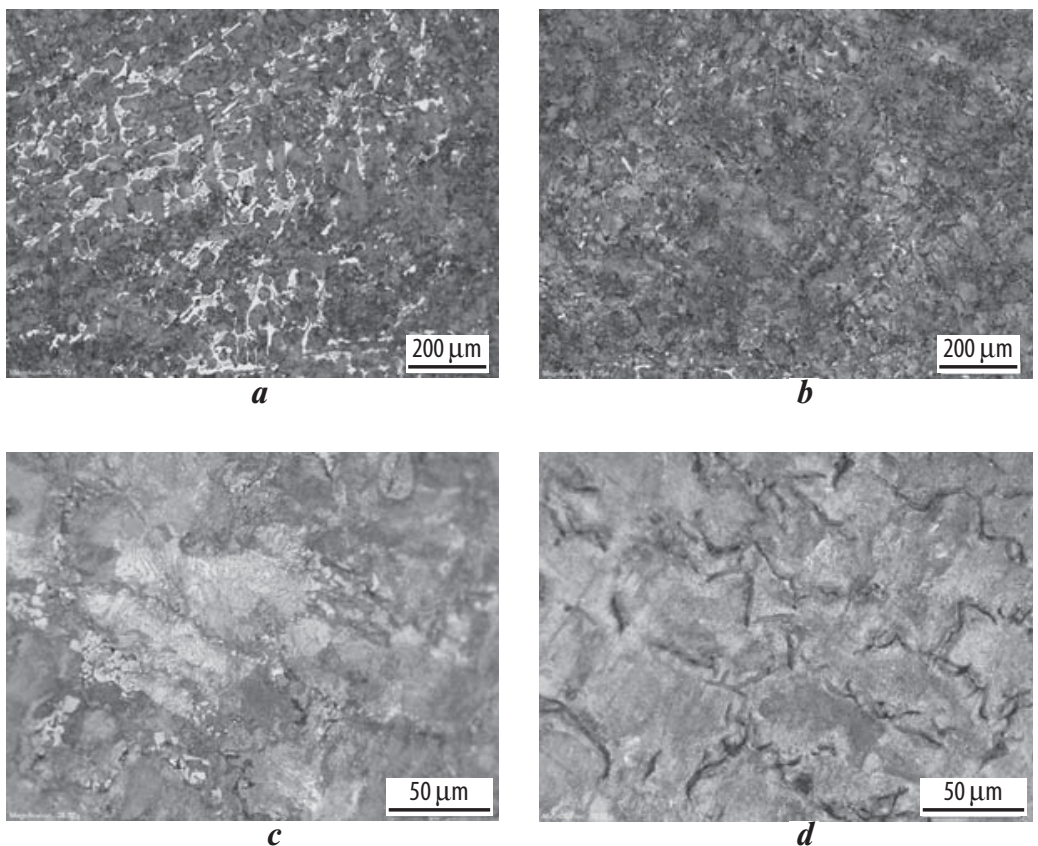

Fig. 4. Real structure of cast iron for control $(a, c)$ and experimental $(b, d)$ castings with different magnification

\begin{tabular}{|l|c|c|c|c|}
\hline \multicolumn{6}{|c|}{ Table 2. Mechanical properties of iron castings } \\
\hline Casting & $\begin{array}{c}\text { Tensile strength } \\
\sigma_{\mathrm{B}}, \mathrm{N} / \mathrm{mm}^{2}\end{array}$ & $\begin{array}{c}\text { Relative } \\
\text { elongation } \delta_{5}, \%\end{array}$ & $\begin{array}{c}\text { Impact toughness } \\
\mathrm{KCU}+20, \mathrm{~J} / \mathrm{cm}^{2}\end{array}$ & $\begin{array}{c}\text { Hardness, } \\
\mathrm{HB}\end{array}$ \\
\hline Control & 180 & 2.0 & 1.25 & 177 \\
\hline Experimental & 310 & 2.2 & 1.9 & 241 \\
\hline
\end{tabular}

2 times via mould blowing by compressed air in the dendrite crystallization interval. It had a serious effect on forming of large amount of primary austenite dendrite crystallization and, respectively, on forming more dispersed structure. The distances between the second order branches for the control and experimental castings are equal to $\lambda_{\mathrm{K}}=34 \mu \mathrm{m}$ and $\lambda_{\mathrm{o}}=25 \mu \mathrm{m}$ respectively (Fig. 2 ).

Afterwards the burning reaction in the mix layers adjacent to the casting was initiated in the eutectic transformation interval and it was conducted due to heating of mix layers up to the inflammation temperature of combustible additives. At this moment retarding of the casting cooling rate led to forming of austenite-graphite eutectics. The size of eutectic cells practically didn't increase in this case (Fig. 3).

Decrease of overcooling rate during eutectic crystallization and lowering of heat removal in the period of forming the small secondary carbides for adjusting cooling procedures varied structure and properties of iron castings in desired direction.

The real structure of the control and experimental castings was determined with 100 fold magnification for determination of metal base and with 500 fold magnification for evaluation of laminar pearlite dispersity (Fig. 4) [21].

Pearlite metallic base was formed in the experimental casting (Fig. 4, b), otherwise than for pearlite-ledeburite base of the control casting (Fig. 4, a) that is typical for mottled iron. Pearlite dispersity in the experimental casting differs from 0.3 to $0.8 \mu \mathrm{m}$ (Fig. 4, $d$ ) and from 1.3 to $1.6 \mu \mathrm{m}$ (Fig. 4, c). It testifies about positive influence of secondary blowing in the eutectoid transformation interval, what finalizes in decrease of the distance between ferrite and cementite plates more than by 2 times.

Such variations in structure forming for the experimental casting led to improvement of cast iron mechanical properties. Metal mechanical properties for the experimental and control castings are presented in the Table 2.

Improvement of mechanical properties can be characterized by rise of tensile strength (metal rupture for experimental casting) by $72 \%$, hardness - by $36 \%$, relative elongation by $10 \%$ and impact toughness by $52 \%$.

Such complex and multi-directional effect of iron cooling rate in the structurally sensitive solidification intervals allowed to increase tensile strength and metal hardness for the experimental casting together with a slight rise of ductile parameters (elongation and toughness). 


\section{Conclusions}

It was found out that usage of adjustment of solidification rate for iron castings in the structurally sensitive intervals allows to improve substantially metal mechanical properties without introduction of additional alloying additives. Practically the same technological operation provides cooling and heating of a casting mould with rates that are sufficient for directional variation of structure and properties of grey iron - casting alloy that is sensitive to thermokinetics. It is shown that putting into practice of the suggested innovation will be accompanied by increase of number of technological operations. However, necessity of more strict control of technological parameters and, consequently, increase of labour intensity of casting production as well as adaptation of this technical solution in the conditions of manufacture of thin-walled special critical duty castings with high risks of chilling appearance are rather justified and make this innovation quite attractive in comparison with the existing technologies based on alloying and modifying.

\section{REFERENCES}

1. Zhukov A. A., Silman G. I., Levi L. I. et al. Directory on iron casting. Edited by Girshovich N. G. 3rd edition. Leningrad., Mashinostroenie. $1978.758 \mathrm{p}$.

2. Leushin I. O., Korovin V. A. Relation between modification and graphitization processes in cast iron. Chernye metally. 2010. No. 7. pp. 30-32.

3. Stefan E., Riposan I., Chisamera M. Application of thermal analysis in solidification pattern control of La-inoculated grey cast irons. J. Therm. Anal. Calorim. 2019. Vol. 138. pp. 2491-2503.

4. Kolokoltsev V. M., Petrochenko E. V., Molochkova O. S. Effect of niobium addition on the structural-phase composition, mechanical and special properties of cast irons based on the $\mathrm{Cr}-$ Mn-Ni-Ti-system. Chernye metally. 2019. No. 2. pp. 18-24.

5. Girshovich N. G. Crystallization and iron properties in castings. M., Metallurgiya. 1979. 562 p.

6. Kolokoltsev V. M., Petrochenko E. V., Molochkova O. S. Influence of complex $\mathrm{V}, \mathrm{Cu}, \mathrm{Ti}$ and $\mathrm{B}$ alloying on structural and phase state, mechanical properties and wear resistance of white cast iron. CIS Iron and Steel Review. 2016. Vol. 11. pp. 23-29.
7. Bunin K. P., Taran Yu. N. Cast iron structure. M., Metallurgiya. $1972.160 \mathrm{p}$

8. Bogachev I. N., Dubinin N. P., Egorenkov I. P. et al. Directory of a caster. Iron casting. Edited by Rubtsov N. N. M., Mashgiz. $1961.774 \mathrm{p}$.

9. Glicksman M. E. Principles of solidification, an introduction to modern casting and crystal growth concepts. 2010. New York, Springer Verlag.

10. Christian J. W. The theory of transformations in metals and alloys. Oxford, Elsevier Science Ltd. 2002. 1200 p.

11. Hong Nga P. T., Ngoc Thien T., Josepha Pritadewi P., Phuong V. N. Y. Research on Factors Influencing the Formation Graphite and Effect of Graphite on Mechanical Properties of Grey Cast Iron. International Conference on System Science and Engineering (ICSSE), Dong Hoi, Vietnam. 2019. pp. 619-629.

12. Mingguo X., Changan Z., Jianxin Z. Bidirectional impact of undercooling on eutectic structural formation of hypoeutectic grey iron and its physical connotation. Materials Research Innovations. 2015. Vol. 19. pp. S5157-S5162.

13. Górny M., Tyrała E. Effect of cooling rate on microstructure and mechanical properties of thin-walled ductile iron castings. J. Mater. Eng. Perform. 2013. Vol. 22 (1). pp. 300-305.

14. Ilyinskiy V. A., Gulevskiy V. A., Kostyleva L. V., Gabelchenko N. I., Pozharskiy A. V. RF Patent 2156673 RF, MPK 7 B 22 D 27/04. Volgograd State Technical University. 2000.

15. Kostyleva L. V., Ilyinskiy V. A., Gabelchenko N. I., Pozharskiy A. V., Gulevskiy V. A. Study of the cooling modes of iron castings. Liteinoe proizvodstvo. 1999. No. 2. pp. 9-11.

16. Gabelchenko N. I., Belov A. A. Meshcheryakova O. A. Production of High-Quality Castings from Gray Iron by Differentiated Cooling in Iron Mould. Materials Science Forum. 2019. Vol. 973 : Proc. of IX Int. Sci. and Techn. Conf. on Engineering - Innovation Technol. in Eng.: From Design to Production of Competitive Products (Volgograd, Sept. 2017). Volgograd St. Techn. Univ. pp. 15-20.

17. Gabelchenko N. I., Khantimirova S. B., Shtepina E. V. Study of local intervals of steel and iron crystallization process via the method of differential thermal analysis. Izvestiya VolgGTU. Series "Problems of material science, welding and strength in machine-building”. 2016. No. 9 (188). pp. 113-116.

18. Kidalov N. A., Gabelchenko N. I., Belov A. A., Savchenko A. Selection of exothermic carbon-containing additives for regulating the cooling mode of iron castings. Chernye metally. 2020. No. 7. pp. 23-27.

19. Sofroni L., Riposan I., Brabie V., Chisamera M. Cast iron. Bucharest, Romania: Editura Didactica si Pedagogica Publisher [Romanian language]. 1985. p. 36-49.

20. Kovalenko V. S. Metallographic reaction agents. Directory. $3^{\text {rd }}$ edition. M., Metallurgiya. 1981. $121 \mathrm{p}$.

21. GOST 3443-87. Iron castings with different graphite form. Methods of structure determination. Intr. 01.07.1988.

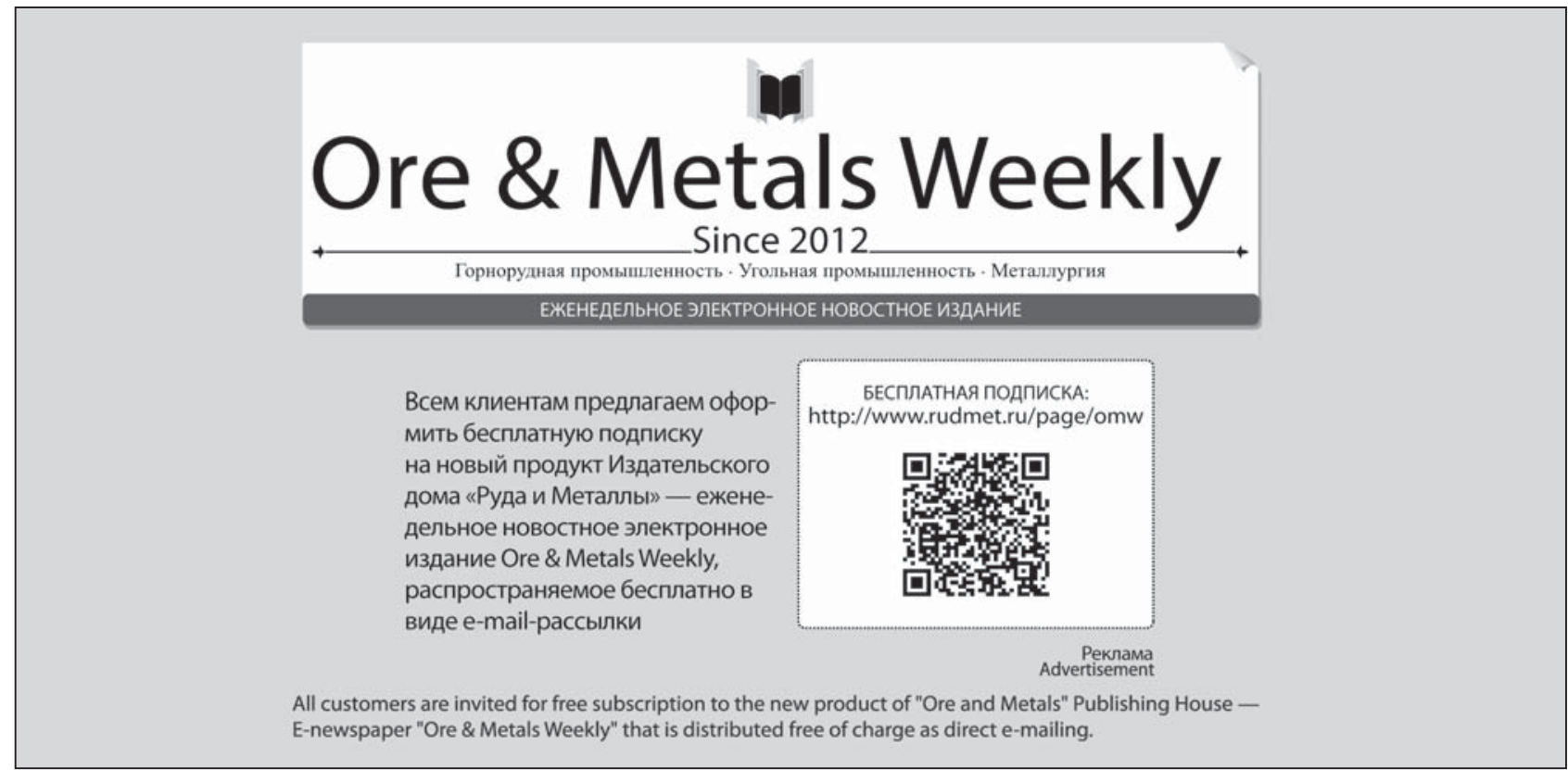

